of India; the defects and the beauties of the religions of India are set forth; the testing of the Bible in India is shown, the nuethod and success in presenting Christ to. Hindus is outlined; medical missions, women's work and educational successes are discussed; the hindrances to winning converts are shown; the proofs of the power of Christianity in India are adduced from many sources. It is an optimistic picture of missionary work with faithful seeing and presenting of actual situations.

The biographical sketch, all too brief, is a fine presentation of an unostentatious hero of the great cause of human redemption. It will inspire every sympathetic reader and quicken his pur pose to share in the work.

Dr. Chamberlain was a clear, profound student of conditions and the master of a most effective style in presenting his subject. This book will help very many to more distinct knowledge of India and the progress of Christ's work in that land.

W. O. Carver.

\title{
THE SIFTING OF PHILIP.
}

By Everett T. Tomlinson. Phlladelphis: The Grimth \& Rowland Press, 1908. Pages 297. Price \$1.25.

This is a story of home mission life in the Northwestern States, such as Dr. Tomlinson has written for various phases of religious work. It is vigorous, full of action, sometimes intense in interest. It presents well the normal life of a frontier missionary in the earlier days of the development of any section. 'The struggles, the manly devotion, the effective service of the missionary and the experiences of his family are faithfully presented. There is also the cowboy, the health seeker, the life of the plains, with the man running away from an undesirable pest. And there is the necessary love story. Such works can seldom rise to the first rank as literature, and must always sacrifice something of accuracy for the sake of the romantic element. But many will read such a story of the spiritual "winning of the West" who would not give time for the more direct narrative. This is a good book.

W. O. Carver. 